\title{
MENYELISIK KEPATUHAN PAJAK PELAKU UMKM DI WILAYAH JABODETABEK DARI PERSPEKTIF CREATIVE TAX MORALE
}

\author{
Maritsa Agasta Putri \\ Politeknik Keuangan Negara STAN \\ Arief Budi Wardana \\ Politeknik Keuangan Negara STAN
}

\begin{abstract}
The reason why people pay taxes is still questionable in various tax compliance literatures. Tax morale is believed to be one of the factors that motivate people to pay taxes. This study aims to analyze the determinants of tax morale in influencing the level of tax compliance. Using a questionnaire survey and a multivariate test procedure, this study shows that tax morale and tax compliance can be increased by decreasing the level of corruption, improving the efficiency of government spending, increasing fairness in the taxation system, reducing tax rates, and addressing financial constraints. In addition, this study also proves that there is significant difference on tax morale between age category, while other socio-demographic and socio-economic categories have no significant difference. The results of this study are expected to add references in the tax compliance literature and become a consideration for tax authorities in improving tax compliance.
\end{abstract}

Keywords: tax morale, tax compliance, MSME.

\begin{abstract}
ABSTRAK
Alasan seseorang membayar pajak masih menjadi pertanyaan dalam berbagai literatur kepatuhan pajak. Tax morale diyakini sebagai salah satu motivasi seseorang membayar pajak. Penelitian ini bertujuan untuk menganalisis faktor-faktor penentu tax morale dalam mempengaruhi tingkat kepatuhan pajak. Dengan menggunakan survei kuesioner dan serangkaian prosedur pengujian analisis mutivariat, penelitian ini membuktikan bahwa dengan menurunkan tingkat korupsi, meningkatkan efisiensi belanja pemerintah, meningkatkan keadilan dalam sistem perpajakan, menurunkan tarif pajak, dan mengatasi financial constraint dapat meningkatkan tax morale dan tax compliance. Selain itu, dalam penelitian ini juga membuktikan bahwa terdapat perbedaan ratarata tax morale pada kategori usia, sedangkan kategori sosial demografi dan sosial ekonomi lainnya tidak terdapat perbedaan signifikan. Hasil penelitian ini diharapkan dapat menambah referensi dalam literatur kepatuhan pajak dan menjadi bahan pertimbangan bagi otoritas pajak dalam meningkatkan kepatuhan pajak.
\end{abstract}

Kata kunci: tax morale, tax compliance, UMKM.

\section{PENDAHULUAN}

Usaha Mikro, Kecil, dan Menengah (UMKM) memiliki peran penting dalam perekonomian suatu negara, terutama di negara berkembang. UMKM di Indonesia telah memberikan kontribusi yang besar bagi perkembangan ekonomi nasional dan penciptaan lapangan kerja. Pada tahun 2019, jumlah pelaku UMKM mencapai 65,5 juta atau 99,99\% dari jumlah pelaku usaha di Indonesia dengan daya serap tenaga kerja sebanyak 120 juta pekerja atau $97 \%$ dari daya serap tenaga kerja dunia usaha (Kementerian Koperasi UKM, 2020). Selain itu UMKM juga memberikan 


\section{6 | Bina Ekonomi}

kontribusi yang cukup signifikan bagi Produk Domestik Bruto Indonesia yaitu sebesar 60,51\% (Kementerian Koperasi UKM, 2020).

Meskipun UMKM mendominasi perekonomian di Indonesia, kontribusi UMKM terhadap penerimaan pajak masih relatif kecil. Pada tahun 2019 pembayaran PPh UMKM hanya berkontribusi sebesar 1,1\% dari total penerimaan PPh secara keseluruhan (Masduki, 2021). Penelitian yang dilakukan oleh Sari dan Maradona (2020) menunjukkan bahwa rendahnya kepatuhan UMKM disebabkan oleh kesadaran wajib pajak yang masih rendah. Hal ini dapat terjadi karena wajib pajak tidak mendapatkan imbalan secara langsung dari pajak yang dibayarkan. Selain itu pengetahuan pajak yang belum merata dan literasi digital yang terbatas juga menjadi penyebab rendahnya kepatuhan wajib pajak UMKM (Sari \& Maradona, 2020).

Kepatuhan wajib pajak merupakan hal penting bagi Indonesia yang menganut sistem perpajakan self-assessment. Wajib pajak dituntut untuk melaksanakan kewajiban perpajakannya secara jujur dan mandiri serta memiliki tax morale yang baik sehingga memahami pentingnya pajak bagi negara (Sari \& Maradona, 2020). Telah banyak literatur yang meneliti tentang apa sebenarnya yang memotivasi seseorang membayar pajak. Pada awalnya Allingham dan Sandmo (1972) mengembangkan model yang sejalan dengan economic-of-crime yang memberikan pandangan bahwa alat kebijakan yang dapat digunakan untuk menangkal penghindaran pajak adalah tarif pajak, besarnya sanksi, dan kemungkinan terdeteksi. Namun menurut Torgler (2007) model ini mendapat banyak pertentangan dari peneliti lain antara lain, Graetz dan Wilde (1985), Alm, McClelland, dan Schulze (1992), Frey dan Feld (2002) yang menjelaskan bahwa di beberapa negara tingkat kepatuhan pajak masih tinggi, meskipun tarif pajak, besaran sanksi, dan kemungkinan diaudit rendah. Ketidakpatuhan pajak bukan hanya tentang menerapkan hukuman yang lebih tinggi maupun meningkatkan kemungkinan deteksi, tetapi terdapat faktor lain di luar faktor ekonomi yang dapat menjelaskan gap yang terjadi.

Pada tahun 1990an, para peneliti mulai mengangkat tax morale sebagai isu utama dalam penelitian terkait kepatuhan pajak (Horodnic, 2018). Menurut Alm et. al. (1992), terdapat beberapa bukti bahwa kepatuhan tidak selalu untuk menghindari risiko diaudit karena masih terdapat kepatuhan meskipun tidak ada peluang terdeteksi. Errard dan Feinstein (1994) menekankan pentingnya mengintegrasikan sentimen moral ke dalam model untuk memberikan penjelasan yang masuk akal tentang perilaku kepatuhan. Selain itu, Andreoni, Errard, dan Feinstein (1998) menunjukkan bahwa masih terdapat ruang untuk mengembangkan dinamika moral dan sosial ke dalam model kepatuhan. Berdasarkan laporan OECD (2019), pada tingkat global pertanyaan survei berfokus pada justifikasi tax avoidance atau tax evasion, sedangkan terkait tax morale masih terbatas.

Tax morale yang didefinisikan sebagai motivasi intrinsik untuk membayar pajak (Torgler, 2005), merupakan aspek penting dalam sistem perpajakan, karena sebagian besar sistem perpajakan bergantung pada voluntary compliance. Pemahaman yang lebih baik tentang apa yang mendorong perbedaan dalam tax morale merupakan elemen kunci dalam menjelaskan variasi kepatuhan pajak (OECD, 2019).

Tax morale bersifat dinamis seiring berjalannya waktu tergantung kondisi ekonomi, sosial, dan politik yang dialami suatu negara (Frey \& Torgler, 2007; Cevik, 2016). Pada tahun 2020, pandemi COVID-19 memberikan dampak sosial dan ekonomi yang luar biasa secara global. Ekonomi Indonesia sendiri pada tahun 2020 mengalami kontraksi pertumbuhan yang cukup dalam, yaitu sebesar -2,07 dibandingkan tahun sebelumnya (BPS, 2021). Perlu dilakukan pembaharuan untuk mengetahui sejauh mana tax morale suatu negara terutama ketika menghadapi kondisi yang tak biasa. 


\section{7 | Bina Ekonomi}

Tax morale sebagai suatu konsep yang mengutamakan moral dan sentimen masyarakat dalam memenuhi kewajiban perpajakannya dapat menjadi salah satu alternatif kebijakan di masa krisis ekonomi (Bitzenis \& Vlachos, 2018). Dengan konsep tax morale, masyarakat diharapkan akan tetap patuh pada kewajiban perpajakannya ketika menilai pemerintah telah melakukan tugasnya dengan baik dalam memberikan pelayanan dan penyediaan barang publik (Ortega et al., 2015).

Berdasarkan penjelasan di atas, penting untuk mengetahui faktor-faktor yang mempengaruhi tax morale untuk meningkatkan kepatuhan pajak di masa pandemi. Adapun faktor-faktor yang mempengaruhi tax morale menurut Alasfour et al. (2016) adalah persepsi korupsi, efisiensi belanja pemerintah, persepsi keadilan, tarif pajak, dan financial constraint. Penelitian yang dilakukan oleh Alasfour, et al. (2016) mengukur tax morale dengan menggunakan Creative Tax Morale. Creative Tax Morale mengembangkan beberapa pertanyaan untuk menyelidiki apakah alat pengukuran multi-item akan meningkatkan validitas dan keandalan variabel. Menurut Torgler dan Valev (2010), alat pengukuran yang multi-item untuk mengukur kesediaan wajib pajak dalam membayar pajak dapat meningkatkan reliabilitas dan validitas variabel tersebut. Selain itu, merujuk pada penelitian Alasfour, et al. (2016), Creative Tax Morale memberikan bukti yang bertentangan dengan model neoklasikal tax evasion.

Melihat kondisi pandemi yang berdampak pada perekonomian nasional, sektor yang diharapkan paling mampu bertahan di tengah krisis adalah UMKM. Hal ini terbukti pada krisis moneter 1998 dan 2008 sekitar 96\% UMKM bertahan dari goncangan krisis (BI, 2015). Data dari BPS bahkan menunjukkan adanya tren yang meningkat pada sektor UMKM pasca krisis moneter tahun 1998 (BI, 2015). Oleh karena itu, penting untuk meneliti tax morale pada UMKM karena dapat menjadi solusi di tengah pandemi untuk mengamankan penerimaan negara. Selain itu, memahami tax morale pada UMKM dapat memberikan jalan dalam mengatasi tingginya tingkat informalitas (OECD, 2019). Menurut Kacaribu (2020), informalitas pada sektor ini menyebabkan otoritas pajak cenderung sulit memungut pajak yang seharusnya terutang dari UMKM. Dengan menurunkan tingkat informalitas melalui tax morale, upaya otoritas pajak untuk meningkatkan kepatuhan dan menggali potensi penerimaan pajak UMKM diharapkan dapat berjalan lebih optimal.

\section{METODE DAN DATA}

Metode yang digunakan dalam penelitian ini adalah metode kuantitatif dengan melakukan penyebaran kuesioner melalui daring secara convenience sampling kepada pelaku UMKM di wilayah Jabodetabek. Wilayah Jabodetabek dipilih karena merupakan wilayah paling strategis di Indonesia. Letak dan posisinya sebagai ibu kota dan penyangga ibu kota, memiliki pengaruh yang kuat terhadap pertumbuhan ekonomi wilayah di sekitarnya.

Penyebaran kuesioner dilakukan sejak tanggal 28 Juni 2021 sampai dengan 21 Juli 2021. Selama periode penyebaran kuesioner, penulis berhasil mengumpulkan 167 responden. Adapun indikator untuk mengukur variabel dependen dan independen menggunakan Creative Tax Morale yang mengacu pada penelitian yang dilakukan oleh Alasfour, et al. (2016). Berdasarkan penelitian Alasfour, et al. (2016), variabel yang mempengaruhi tax morale adalah variabel persepsi korupsi, efisiensi belanja pemerintah, persepsi keadilan, tarif pajak, dan financial constraint. Pengujian dilakukan menggunakan uji $\mathrm{Z}$ yang membandingkan rata-rata dari setiap pernyataan untuk mengetahui variabel yang paling berpengaruh terhadap tax morale dan diharapkan dapat menjadi fokus perhatian dalam meningkatkan kepatuhan pajak pelaku UMKM.

\section{PEMBAHASAN}


Sebelum melakukan pengujian hipotesis, atas data yang digunakan dalam sampel dilakukan analisis deskriptif. Tabel analisis statistik deskriptif disajikan dalam Lampiran 1. Hasil statistik deskriptif menunjukkan bahwa berdasarkan rata-rata, tax morale wanita lebih tinggi dibandingkan pria dengan tax morale wanita (mean $=4.15, \mathrm{SD}=0.95$ ) lebih baik daripada pria (mean $=4.24, \mathrm{SD}=1.34$ ). Tabel tersebut juga menunjukkan kategori lain dari kelompok usia dimana usia $<30$ tahun memiliki tax morale paling tinggi (mean=3.82, SD=1.39) dibandingkan kelompok usia lainnya. Untuk kategori status perkawinan, jika dilihat dari rata-rata, kelompok yang menikah memiliki tax morale paling tinggi (mean= 4.05, $\mathrm{SD}=1.59$ ) dibandingkan dengan kelompok lainnya. Namun selisih rata-rata untuk kategori ini tidak terlalu jauh dimana tax morale terendah dari kategori ini, yaitu kelompok yang belum menikah memiliki rata-rata 4.20 $(\mathrm{SD}=1.30)$. Berdasarkan rata-rata untuk kategori tingkat pendidikan, tax morale paling rendah justru dimiliki oleh kelompok tingkat pendidikan yang paling tinggi (mean $=4.79, \mathrm{SD}=0.94$ ). Adapun tax morale paling tinggi untuk kategori ini berasal dari kelompok tingkat pendidikan DI/DII/DIII (mean= 3.93, SD=1.41). Untuk kategori jenis usaha, berdasarkan jawaban responden yang berhasil dikumpulkan, tax morale terendah adalah kelompok jenis usaha agrikultur (mean= 4.68, $\mathrm{SD}=0.37$ ), sedangkan kelompok jenis usaha dengan tax morale tertinggi adalah jenis usaha yang bergerak di bidang infomasi (mean $=3.47, \mathrm{SD}=1.66$ ). Berdasarkan kategori omzet usaha, $\operatorname{tax}$ morale paling tinggi adalah kelompok pelaku usaha yang memiliki omzet 300.000.0012.500.000.000 (mean=3.87, $\mathrm{SD}=0.69$ ), sedangkan tax morale paling rendah adalah kelompok pelaku usaha yang memiliki omzet 2.500.000.001-4.800.000.000 (mean $=4.61, \mathrm{SD}=0.62$ ).

Untuk menguji kebenaran hipotesis maka perlu melakukan pengujian statitsik. Dalam penelitian ini, uji yang digunakan adalah uji Z. Uji Z terhadap hipotesis pertama dilakukan untuk menguji perbedaan variabel persepsi korupsi dengan pernyataan lain. Hipotesis akan diterima jika nilai rata-rata pernyataan dari variabel persepsi korupsi lebih tinggi secara signifikan dibandingkan dengan nilai rata-rata 12 pernyataan lainnya. Tingkat signifikansi dalam penelitian ini sebesar $5 \%(\mathrm{Z} \alpha=\mathrm{Z} 0.05=1.645)$. Hipotesis yang digunakan adalah sebagai berikut:

H0: $(\mu$ cor $-\mu \mathrm{i}) \leq 0$

$\mathrm{H} 1:(\mu \mathrm{cor}-\mu \mathrm{i})>0$

Hasil uji z score untuk variabel persepsi korupsi dapat dilihat pada tabel 1 sebagai berikut:

Tabel 1 Hasil Uji Z Variabel Persepsi Korupsi

\begin{tabular}{ccccccc}
\hline Corruption & \multirow{4}{*}{$\mathbf{7 9 3}$} & $\mathbf{1 . 5 1 8}$ & \multicolumn{4}{c}{ H0: $(\boldsymbol{\mu c o r}-\boldsymbol{\mu i}) \leq \mathbf{0}$} \\
\cline { 4 - 7 } & & & \multicolumn{4}{c}{ Ha: $(\mu$ cor- $\boldsymbol{\mu} \mathrm{i})>0$} \\
Statement & Means & Std Dev & Zscore & Z0.05 & p-value & Result \\
\hline $\mathbf{1}$ & 5.251 & 1.891 & -2.444 & 1.645 & 0.496 & Accepted \\
\hline $\mathbf{2}$ & 3.599 & 1.958 & 6.229 & 1.645 & 0.000 & Rejected \\
\hline $\mathbf{3}$ & 5.521 & 1.889 & -3.884 & 1.645 & 0.500 & Accepted \\
\hline $\mathbf{5}$ & 3.341 & 1.975 & 7.530 & 1.645 & 0.000 & Rejected \\
\hline $\mathbf{7}$ & 3.204 & 2.008 & 8.160 & 1.645 & 0.000 & Rejected \\
\hline $\mathbf{8}$ & 3.874 & 2.036 & 4.674 & 1.645 & 0.000 & Rejected \\
\hline $\mathbf{9}$ & 3.377 & 1.894 & 7.536 & 1.645 & 0.000 & Rejected \\
\hline $\mathbf{1 0}$ & 3.228 & 1.910 & 8.291 & 1.645 & 0.000 & Rejected \\
\hline $\mathbf{1 2}$ & 4.096 & 2.060 & 3.521 & 1.645 & 0.000 & Rejected \\
\hline $\mathbf{1 3}$ & 4.856 & 2.066 & -0.320 & 1.645 & 0.313 & Accepted \\
\hline $\mathbf{1 4}$ & 3.976 & 2.012 & 4.188 & 1.645 & 0.000 & Rejected \\
\hline $\mathbf{1 5}$ & 2.760 & 1.845 & 10.993 & 1.645 & 0.000 & Rejected \\
\hline
\end{tabular}

Sumber: Diolah dari Microsoft Excel 2019 
Hipotesis untuk variabel persepsi korupsi akan diterima jika rata-rata nilai kategori ini lebih tinggi dibandingkan dengan rata-rata pernyataan lainnya dengan tingkat signifikansi $5 \%$. Uji hipotesis dapat dilakukan dengan dua cara, baik dengan menghitung selisih antara Z score dengan Z0.05, maupun dengan membandingkan $p$-value dengan tingkat signifikansi 0.05 . Berdasarkan tabel tersebut dapat terlihat bahwa Zscore dari pernyataan 1 bernilai -2.444. Nilai tersebut lebih rendah dibandingkan dengan Z0.05 yaitu 1.645, sehingga H0 diterima. Selain itu, $p$ value untuk pernyataan 1 sama dengan 0.496, sehingga dapat disimpulkan bahwa H0 diterima karena $p$-value lebih tinggi dari tingkat signifikansi yang diterima sebesar 0,05.

Pada tabel 1 juga terlihat bahwa Zscore untuk mayoritas pernyataan lebih tinggi dari 1.645, kecuali untuk pernyataan nomor 1 terkait tarif pajak, 3 terkait persepsi keadilan, dan 13 terkait financial constraint. Oleh karena itu, untuk semua pernyataan selain pernyataan nomor 1 , 3, dan 13, H0 ditolak dan hipotesis yang menyatakan bahwa perbedaan antara rata-rata pernyataan variabel persepsi korupsi dan semua pernyataan lain bernilai lebih dari 0 dapat diterima. Berdasarkan hasil uji Z tersebut, dapat disimpulkan bahwa penghindaran pajak lebih dapat diterima dalam hal uang pajak dikorupsi dibandingkan dengan pernyataan lain. Namun dalam hal tarif pajak tinggi, sistem pajak tidak adil, dan kesulitan keuangan yang dialami seseorang, penghindaran pajak lebih dapat diterima dibandingkan apabila uang pajak dikorupsi.

Tabel 2 Hasil Uji Z Variabel Efisiensi Belanja Pemerintah

\begin{tabular}{ccccccc}
\hline \multirow{2}{*}{$\begin{array}{c}\text { Government } \\
\text { Spending }\end{array}$} & $\mathbf{3 . 3 0 7}$ & $\mathbf{1 . 7 1 1}$ & \multicolumn{4}{c}{ H0: $(\boldsymbol{\mu g o v}-\boldsymbol{\mu i}) \geq \mathbf{0}$} \\
\cline { 4 - 7 } Statement & Means & Std Dev & Zscore & Z0.05 & $\mathrm{p}$-value & Result \\
\hline $\mathbf{1}$ & 5.251 & 1.891 & -9.851 & -1.645 & 0.000 & Rejected \\
\hline $\mathbf{2}$ & 3.599 & 1.958 & -1.449 & -1.645 & 0.037 & Rejected \\
\hline $\mathbf{3}$ & 5.521 & 1.889 & -11.226 & -1.645 & 0.000 & Rejected \\
\hline $\mathbf{4}$ & 5.485 & 2.050 & -10.540 & -1.645 & 0.000 & Rejected \\
\hline $\mathbf{6}$ & 5.138 & 2.197 & -8.496 & -1.645 & 0.000 & Rejected \\
\hline $\mathbf{8}$ & 3.874 & 2.036 & -2.755 & -1.645 & 0.001 & Rejected \\
\hline $\mathbf{1 0}$ & 3.228 & 1.910 & 0.402 & -1.645 & 0.328 & Accepted \\
\hline $\mathbf{1 1}$ & 5.234 & 2.259 & -8.785 & -1.645 & 0.000 & Rejected \\
\hline $\mathbf{1 2}$ & 4.096 & 2.060 & -3.805 & -1.645 & 0.000 & Rejected \\
\hline $\mathbf{1 3}$ & 4.856 & 2.066 & -7.463 & -1.645 & 0.000 & Rejected \\
\hline $\mathbf{1 4}$ & 3.976 & 2.012 & -3.272 & -1.645 & 0.000 & Rejected \\
\hline $\mathbf{1 5}$ & 2.760 & 1.845 & 2.809 & -1.645 & 0.499 & Accepted \\
\hline $\mathbf{1 6}$ & 4.335 & 2.346 & -4.575 & -1.645 & 0.000 & Rejected \\
\hline $\mathbf{1 7}$ & 3.772 & 2.303 & -2.095 & -1.645 & 0.009 & Rejected \\
\hline
\end{tabular}

Sumber: Diolah dari Microsoft Excel 2019

Uji Z terhadap hipotesis kedua dilakukan untuk menguji perbedaan variabel efisiensi belanja pemerintah dengan pernyataan lain. Berbeda dengan persepsi korupsi, hipotesis untuk variabel efisiensi belanja pemerintah akan diterima jika nilai rata-rata pernyataan yang termasuk dalam kategori ini lebih rendah daripada nilai rata-rata pernyataan yang tidak termasuk dalam kategori ini. Apabila dirumuskan, maka hipotesisnya adalah sebagai berikut:

$\mathrm{H} 0:(\mu \mathrm{gov}-\mu \mathrm{i}) \geq 0$

Ha: $(\mu g o v-\mu \mathrm{i})<0$

Hipotesis variabel efisiensi belanja pemerintah diuji menggunakan uji sisi kiri (left-tail test) dan hasilnya ditolak jika $\mathrm{z}<-\mathrm{z} \alpha$ atau $\mathrm{z}<-\mathrm{z} 0.05(-\mathrm{z} \alpha=-\mathrm{z} 0.05=-1.645)$ dengan tingkat signifikansi 5\%. Sebagaimana terlihat pada tabel 2, z-score untuk efisiensi belanja pemerintah lebih kecil dari -1.645 untuk semua pernyataan kecuali pernyataan 10 terkait referent group dan 
15 terkait personal interest. H0 ditolak untuk mayoritas pernyataan jika dibandingkan dengan pernyataan efisiensi belanja publik. Hal ini menunjukkan bahwa pernyataan tersebut merupakan argumen yang lemah untuk mendukung penghindaran pajak, kecuali pernyataan 10 dan 15. Oleh karena itu, hipotesis bahwa perbedaan antara rata-rata dari pernyataan efisiensi belanja pemerintah dan semua pernyataan, selain nomor 10 dan 15, lebih rendah dari 0 diterima. Artinya, penghindaran pajak kurang dapat diterima ketika pemerintah membelanjakan uang pajak secara efektif kecuali ketika orang lain dianggap melakukan penghindaran pajak (pernyataan 10) atau ketika dengan melakukan penghindaran pajak dapat memberi keuntungan bagi orang tersebut (pernyataan 15).

Tabel 3 Hasil Uji Z Variabel Persepsi Keadilan

\begin{tabular}{|c|c|c|c|c|c|c|}
\hline \multirow[t]{2}{*}{ Fairness } & \multirow[t]{2}{*}{5.521} & \multirow[t]{2}{*}{1.889} & \multicolumn{4}{|c|}{ H0: $(\mu$ fair $-\mu \mathrm{i}) \leq 0$} \\
\hline & & & \multicolumn{4}{|c|}{ Ha: $(\mu$ fair $-\mu \mathrm{i})>0$} \\
\hline Statement & Means & Std Dev & Zscore & $\mathrm{Z} 0.05$ & $\mathrm{p}$-value & Result \\
\hline 1 & 5.251 & 1.891 & 1.303 & 1.645 & 0.048 & Rejected \\
\hline 2 & 3.599 & 1.958 & 9.131 & 1.645 & 0.000 & Rejected \\
\hline 4 & 5.485 & 2.050 & 0.167 & 1.645 & 0.217 & Accepted \\
\hline 5 & 3.341 & 1.975 & 10.307 & 1.645 & 0.000 & Rejected \\
\hline 6 & 5.138 & 2.197 & 1.710 & 1.645 & 0.022 & Rejected \\
\hline 7 & 3.204 & 2.008 & 10.865 & 1.645 & 0.000 & Rejected \\
\hline 8 & 3.874 & 2.036 & 7.662 & 1.645 & 0.000 & Rejected \\
\hline 9 & 3.377 & 1.894 & 10.357 & 1.645 & 0.000 & Rejected \\
\hline 10 & 3.228 & 1.910 & 11.033 & 1.645 & 0.000 & Rejected \\
\hline 11 & 5.234 & 2.259 & 1.262 & 1.645 & 0.052 & Accepted \\
\hline 12 & 4.096 & 2.060 & 6.590 & 1.645 & 0.000 & Rejected \\
\hline 13 & 4.856 & 2.066 & 3.069 & 1.645 & 0.001 & Rejected \\
\hline 14 & 3.976 & 2.012 & 7.235 & 1.645 & 0.000 & Rejected \\
\hline 15 & 2.760 & 1.845 & 13.512 & 1.645 & 0.000 & Rejected \\
\hline 16 & 4.335 & 2.346 & 5.087 & 1.645 & 0.000 & Rejected \\
\hline 17 & 3.772 & 2.303 & 7.588 & 1.645 & 0.000 & Rejected \\
\hline
\end{tabular}

Uji Z terhadap hipotesis ketiga dilakukan untuk menguji perbedaan variabel persepsi keadilan dengan pernyataan lain. Untuk variabel persepsi keadilan, hipotesis akan diterima jika rata-rata nilai kategori ini lebih tinggi dibandingkan dengan rata-rata pernyataan lainnya dengan tingkat signifikansi 5\%. Indikator untuk menilai persepsi keadilan dapat dilihat pada pernyataan nomor 3. Pengujian ini akan menentukan apakah perbedaan pernyataan nomor 3 dengan pernyataan lainnya positif dan signifikan secara statistik. Hipotesis variabel persepsi keadilan diuji menggunakan uji sisi kanan (right-tail test) dan $\mathrm{HO}$ ditolak jika $\mathrm{z}>\mathrm{z} \alpha$ atau $\mathrm{z}>\mathrm{z} 0.05$ (z $\alpha=$ z0.05 = 1.645) dengan tingkat signifikansi 5\%.

Berdasarkan tabel 3 dapat dilihat rata-rata sampel untuk pernyataan nomor 3 dibandingkan dengan pernyataan lain. Dengan melihat perbandingan rata-rata pernyataan nomor 3 dengan pernyataan lain dapat disimpulkan bahwa HO ditolak kecuali untuk pernyataan 4 dan 11. Pernyataan 4 dan 11 digunakan sebagai indikator untuk mengukur variabel persepsi korupsi. Hal ini menunjukkan bahwa tingkat penghindaran pajak lebih dapat diterima ketika sistem perpajakan tidak adil dibandingkan dengan pernyataan lain, kecuali dalam hal uang pajak yang dikumpulkan tidak dimanfaatkan dengan baik (pernyataan 4) dan uang pajak dikorupsi (pernyataan 11). 
Tabel 4 Hasil Uji Z Variabel Tarif Pajak

\begin{tabular}{ccccccc}
\hline \multirow{2}{*}{ Tax Rate } & $\mathbf{5 . 2 5 1}$ & $\mathbf{1 . 8 9 1}$ & \multicolumn{4}{c}{ H0: $(\boldsymbol{\mu t a x r a t e}-\boldsymbol{\mu i}) \leq \mathbf{0}$} \\
\cline { 4 - 7 } & & & Ha: $(\boldsymbol{\mu t a x r a t e}-\mu \mathrm{i})>0$ \\
\hline Statement & Means & Std Dev & Zscore & Z0.05 & p-value & Result \\
\hline $\mathbf{2}$ & 3.599 & 1.958 & 7.846 & 1.645 & 0.000 & Rejected \\
\hline $\mathbf{3}$ & 5.521 & 1.889 & -1.303 & 1.645 & 0.452 & Accepted \\
\hline $\mathbf{4}$ & 5.485 & 2.050 & -1.082 & 1.645 & 0.430 & Accepted \\
\hline $\mathbf{5}$ & 3.341 & 1.975 & 9.026 & 1.645 & 0.000 & Rejected \\
\hline $\mathbf{6}$ & 5.138 & 2.197 & 0.507 & 1.645 & 0.153 & Accepted \\
\hline $\mathbf{7}$ & 3.204 & 2.008 & 9.595 & 1.645 & 0.000 & Rejected \\
\hline $\mathbf{8}$ & 3.874 & 2.036 & 6.404 & 1.645 & 0.000 & Rejected \\
\hline $\mathbf{9}$ & 3.377 & 1.894 & 9.048 & 1.645 & 0.000 & Rejected \\
\hline $\mathbf{1 0}$ & 3.228 & 1.910 & 9.730 & 1.645 & 0.000 & Rejected \\
\hline $\mathbf{1 1}$ & 5.234 & 2.259 & 0.079 & 1.645 & 0.234 & Accepted \\
\hline $\mathbf{1 2}$ & 4.096 & 2.060 & 5.341 & 1.645 & 0.000 & Rejected \\
\hline $\mathbf{1 3}$ & 4.856 & 2.066 & 1.824 & 1.645 & 0.017 & Rejected \\
\hline $\mathbf{1 4}$ & 3.976 & 2.012 & 5.969 & 1.645 & 0.000 & Rejected \\
\hline $\mathbf{1 5}$ & 2.760 & 1.845 & 12.183 & 1.645 & 0.000 & Rejected \\
\hline $\mathbf{1 6}$ & 4.335 & 2.346 & 3.929 & 1.645 & 0.000 & Rejected \\
\hline $\mathbf{1 7}$ & 3.772 & 2.303 & 6.414 & 1.645 & 0.000 & Rejected \\
\hline
\end{tabular}

Sumber: Diolah dari Microsoft Excel 2019

Uji Z terhadap hipotesis keempat dilakukan untuk menguji perbedaan variabel tarif pajak dengan pernyataan lain. Hipotesis untuk tarif pajak akan diterima jika rata-rata nilai kategori ini lebih tinggi dibandingkan dengan rata-rata pernyataan lainnya dengan tingkat signifikansi 5\%. Indikator untuk mengukur tarif pajak dapat dilihat pada pernyataan nomor 1 . Pengujian ini akan menentukan apakah perbedaan pernyataan nomor 1 dengan pernyataan lainnya positif dan signifikan secara statistik. Hipotesis variabel tarif pajak diuji menggunakan uji sisi kanan (righttail test) dan $\mathrm{H} 0$ ditolak jika $\mathrm{z}>\mathrm{z} \alpha$ atau $\mathrm{z}>\mathrm{z} 0.05(\mathrm{z} \alpha=\mathrm{z} 0.05=1.645)$ dengan tingkat signifikansi $5 \%$.

Berdasarkan tabel 4 dapat dilihat rata-rata sampel untuk pernyataan nomor 1 dibandingkan dengan pernyataan lain. Dengan melihat perbandingan rata-rata pernyataan nomor 1 dengan pernyataan lain dapat disimpulkan bahwa H0 ditolak kecuali untuk pernyataan 3, 4, 6, dan 11. Pernyataan 3 digunakan sebagai indikator untuk mengukur variabel persepsi keadilan, sedangkan pernyataan 4, 6, dan 11 digunakan sebagai indikator untuk mengukur variabel persepsi korupsi. Hal ini menunjukkan bahwa tingkat penghindaran pajak lebih dapat diterima ketika tarif pajak tinggi dibandingkan dengan pernyataan lain, kecuali dalam hal sistem perpajakan tidak adil atau uang pajak dikorupsi.

Tabel 5 Hasil Uji Z Variabel Financial Constraint

\begin{tabular}{ccccccc}
\hline \multirow{2}{*}{$\begin{array}{c}\text { Financial } \\
\text { Constraint }\end{array}$} & $\mathbf{4 . 8 5 6}$ & $\mathbf{2 . 0 6 6}$ & \multicolumn{4}{c}{ H0: $(\boldsymbol{\mu}$ financial- $\boldsymbol{\mu i}) \leq \mathbf{0}$} \\
\cline { 4 - 7 } Statement & Means & Std Dev & Zscore & Z0.05 & p-value & Result \\
\hline $\mathbf{1}$ & 5.251 & 1.891 & -1.824 & 1.645 & 0.483 & Accepted \\
\hline $\mathbf{2}$ & 3.599 & 1.958 & 5.710 & 1.645 & 0.000 & Rejected \\
\hline $\mathbf{3}$ & 5.521 & 1.889 & -3.069 & 1.645 & 0.499 & Accepted \\
\hline $\mathbf{4}$ & 5.485 & 2.050 & -2.792 & 1.645 & 0.499 & Accepted \\
\hline
\end{tabular}




\begin{tabular}{ccccccc}
\hline $\mathbf{5}$ & 3.341 & 1.975 & 6.850 & 1.645 & 0.000 & Rejected \\
\hline $\mathbf{6}$ & 5.138 & 2.197 & -1.206 & 1.645 & 0.443 & Accepted \\
\hline $\mathbf{7}$ & 3.204 & 2.008 & 7.415 & 1.645 & 0.000 & Rejected \\
\hline $\mathbf{8}$ & 3.874 & 2.036 & 4.375 & 1.645 & 0.000 & Rejected \\
\hline $\mathbf{9}$ & 3.377 & 1.894 & 6.820 & 1.645 & 0.000 & Rejected \\
\hline $\mathbf{1 0}$ & 3.228 & 1.910 & 7.481 & 1.645 & 0.000 & Rejected \\
\hline $\mathbf{1 1}$ & 5.234 & 2.259 & -1.593 & 1.645 & 0.472 & Accepted \\
\hline $\mathbf{1 2}$ & 4.096 & 2.060 & 3.369 & 1.645 & 0.000 & Rejected \\
\hline $\mathbf{1 4}$ & 3.976 & 2.012 & 3.945 & 1.645 & 0.000 & Rejected \\
\hline $\mathbf{1 5}$ & 2.760 & 1.845 & 9.779 & 1.645 & 0.000 & Rejected \\
\hline $\mathbf{1 6}$ & 4.335 & 2.346 & 2.154 & 1.645 & 0.008 & Rejected \\
\hline $\mathbf{1 7}$ & 3.772 & 2.303 & 4.528 & 1.645 & 0.000 & Rejected \\
\hline
\end{tabular}

Sumber: Diolah dari Microsoft Excel 2019

Uji Z terhadap hipotesis terakhir dilakukan untuk menguji perbedaan variabel financial constraint dengan pernyataan lain. Hipotesis untuk financial constraint akan diterima jika ratarata nilai kategori ini lebih tinggi dibandingkan dengan rata-rata pernyataan lainnya dengan tingkat signifikansi 5\%. Indikator untuk menilai persepsi keadilan dapat dilihat pada pernyataan nomor 13. Pengujian ini akan menentukan apakah perbedaan pernyataan nomor 13 dengan pernyataan lainnya positif dan signifikan secara statistik. Hipotesis variabel financial constraint diuji menggunakan uji sisi kanan (right-tail test) dan $\mathrm{H} 0$ ditolak jika $\mathrm{z}>\mathrm{z} \alpha$ atau z $>\mathrm{z} 0.05$ ( $\mathrm{z} \alpha=$ z0.05 = 1.645) dengan tingkat signifikansi 5\%.

Berdasarkan tabel 5 dapat dilihat rata-rata sampel untuk pernyataan nomor 13 dibandingkan dengan pernyataan lain. Dengan melihat perbandingan rata-rata pernyataan nomor 13 dengan pernyataan lain dapat disimpulkan bahwa $\mathrm{H} 0$ ditolak kecuali untuk pernyataan 1, 3, 4, dan 11. Pernyataan 1 sebagai indikator tarif pajak, pernyataan 3 sebagai indikator persepsi keadilan, serta pernyataan 4 dan 11 digunakan sebagai indikator untuk mengukur variabel persepsi korupsi. Hal ini menunjukkan bahwa tingkat penghindaran pajak lebih dapat diterima ketika seseorang mengalami kesulitan keuangan dibandingkan dengan variabel lain, kecuali dalam tarif pajak tinggi, sistem pajak tidak adil, dan uang pajak dikorupsi.

Selain melakukan uji hipotesis antar faktor penentu tax morale, dalam penelitian ini juga menyajikan perbedaan antara faktor penentu tax morale dengan faktor sosial demografi dan sosial ekonomi. Hasil one-way ANOVA untuk variabel kontrol dalam kaitannya dengan variabel tax morale dapat dilihat pada tabel 6 berikut ini:

Tabel 6 Analisis Varians-Faktor Demografi

\begin{tabular}{llrrrrr}
\hline \multicolumn{1}{c}{ Variabel } & \multicolumn{1}{c}{$\begin{array}{c}\text { Sum of } \\
\text { Squares }\end{array}$} & df & $\begin{array}{c}\text { Mean } \\
\text { Square }\end{array}$ & F & Sig. \\
\hline \multirow{2}{*}{ Jenis } & Between Groups & 0.287 & 1 & 0.287 & 0.244 & 0.622 \\
\cline { 2 - 7 } & Within Groups & 194.143 & 165 & 1.177 & & \\
\cline { 2 - 7 } Usia & Total & 194.431 & 166 & & & \\
\cline { 2 - 8 } & Between Groups & 12.747 & 3 & 4.249 & 3.812 & 0.011 \\
\cline { 2 - 8 } & Within Groups & 181.683 & 163 & 1.115 & & \\
\hline Pendidikan & Between Groups & 194.431 & 166 & & & \\
\cline { 2 - 8 } & Within Groups & 188.339 & 3 & 2.113 & 1.831 & 0.144 \\
\cline { 2 - 7 } & Total & 194.431 & 166 & 1.154 & & \\
\hline Jenis Usaha & Between Groups & 2.314 & 7 & 0.331 & 0.274 & 0.963 \\
\hline
\end{tabular}




\begin{tabular}{llrrrrr}
\hline & Within Groups & 192.117 & 159 & 1.208 & & \\
\cline { 2 - 7 } & Total & 194.431 & 166 & & & \\
\hline \multirow{2}{*}{$\begin{array}{l}\text { Status } \\
\text { Perkawinan }\end{array}$} & Between Groups & 0.382 & 3 & 0.127 & 0.107 & 0.956 \\
\cline { 2 - 7 } & Within Groups & 194.049 & 163 & 1.190 & & \\
\cline { 2 - 7 } & Total & 194.431 & 166 & & & \\
\hline \multirow{2}{*}{$\begin{array}{l}\text { Omzet per } \\
\text { tahun }\end{array}$} & Between Groups & 5.300 & 3 & 1.767 & 1.523 & 0.211 \\
\cline { 2 - 7 } & Within Groups & 189.130 & 163 & 1.160 & & \\
\cline { 2 - 7 } & Total & 194.431 & 166 & & & \\
\hline
\end{tabular}

Sumber: Diolah dari output aplikasi SPSS 25

Hipotesis yang diuji adalah

H0: Tidak terdapat perbedaan rata-rata tax morale antar kategori

H1: Terdapat perbedaan rata-rata tax morale antar kategori

Kriteria pengujiannya adalah tolak H0 jika probabilitas < tingkat signifikansi 0.05. Nilai uji F pada tabel 6 menunjukkan bahwa nilai signifikansi sebesar 0.011 pada kategori usia sehingga dapat disimpulkan bahwa terdapat perbedaan rata-rata tax morale antar kategori usia. Sementara pada variabel karakteristik lainnya tidak terdapat perbedaan terhadap tax morale.

Selanjutnya dilakukan analisis lanjutan untuk menunjukkan perbedaan signifikan ratarata antar variabel berdasarkan kondisi sosial demografi dan sosial ekonomi responden. Jika kategori terdiri dari dua kelompok seperti jenis kelamin (laki-laki dan perempuan), maka untuk menguji perbedaan signifikan antara dua rata-rata menggunakan uji $t$, sedangkan kategori lain yang terdiri lebih dari dua kelompok menggunakan uji ANOVA. Hasil uji t dan ANOVA untuk mengetahui perbedaan signifikan rata-rata antar variabel dapat dilihat pada tabel 7 sebagai berikut:

Tabel 7 Perbedaan Rata-Rata Antar Variabel (uji t dan ANOVA)

\begin{tabular}{lcccccc}
\hline & TM & COR & GOV & FAIR & HTR & FIN \\
\hline $\begin{array}{l}\text { Jenis } \\
\begin{array}{l}\text { Kelamin } \\
\text { (Uji t) }\end{array}\end{array}$ & 0.0896 & 0.2506 & $-0.4743^{*}$ & 0.1092 & -0.1697 & 0.2087 \\
\hline Usia & $3.812^{* *}$ & 1.140 & $2.884^{* *}$ & $3.264^{* *}$ & 1.917 & $2.412^{*}$ \\
\hline Pendidikan & 1.831 & 1.498 & 0.963 & 0.583 & 0.570 & 1.538 \\
\hline Jenis Usaha & 0.274 & 0.773 & 0.842 & 1.009 & 0.801 & 1.213 \\
\hline $\begin{array}{l}\text { Status } \\
\text { Perkawinan }\end{array}$ & 0.107 & 0.465 & 0.326 & 0.556 & $4.002^{* * *}$ & 0.900 \\
\hline $\begin{array}{l}\text { Omzet per } \\
\text { tahun }\end{array}$ & 0.0896 & 0.2506 & $-0.4743^{*}$ & 0.1092 & -0.1697 & 0.2087 \\
& & & & & &
\end{tabular}

Sumber: Diolah dari output aplikasi SPSS 25

Keterangan: * prob $<10 \%$ (cukup signifikan); ${ }^{* *}$ prob $<5 \%$ (signifikan); ${ }^{* * *}$ prob $<1 \%$ (sangat signifikan)

Hipotesis yang diuji adalah

H0: Tidak terdapat perbedaan rata-rata tax morale antar kategori

H1: Terdapat perbedaan rata-rata tax morale antar kategori

Berdasarkan tabel 7 dapat dilihat kategori usia memiliki perbedaan signifikan pada tax morale $(\mathrm{F}=3.812)$ dengan tingkat signifikansi $\mathrm{p}<5 \%$. Uji ANOVA juga membuktikan terdapat perbedaan signifikan rata-rata kategori usia untuk variabel efisiensi belanja pemerintah, persepsi keadilan, dan financial constraint masing-masing $\mathrm{F}=2.884(\mathrm{p}<5 \%) ; \mathrm{F}=3.264(\mathrm{p}<5 \%) ; \mathrm{F}=2.412$ ( $\mathrm{p}$ $<10 \%$ ). Untuk kategori usia, kelompok yang memiliki tax morale paling tinggi adalah kelompok usia di bawah 30 tahun. Hal ini mungkin disebabkan kelompok usia tersebut memiliki 
kemampuan literasi digital untuk mengakses pengetahuan pajak dan memenuhi kewajiban perpajakan yang lebih tinggi dibandingkan kelompok usia lainnya. Kemudian untuk kelompok tax morale tertinggi selanjutnya adalah kelompok usia di atas 49 tahun. Hal ini dapat disebabkan pada kelompok usia tersebut lebih menghindari perbuatan yang menyebabkan suatu risiko terjadi (risk avoidance) seperti risiko dari melakukan penghindaran pajak. Orang yang lebih tua cenderung lebih sensitif terhadap ancaman sanksi perpajakan (Torgler \& Schaltegger, 2005). Hasil ini sejalan dengan penelitian yang dilakukan oleh Clotfelter (1983). Dalam penelitian yang dilakukan Clotfelter (1983) menggunakan sampel yang cukup besar sebanyak hampir 47.000 wajib pajak, hasilnya menunjukkan bahwa segmen populasi termuda dan tertua merupakan kelompok yang paling tinggi kepatuhannya. Adapun kelompok usia tengah cenderung untuk tidak patuh.

Selain itu, untuk kategori status perkawinan terdapat perbedaan signifikan untuk variabel tarif pajak $(\mathrm{F}=4.002, \mathrm{p}<1 \%)$. Untuk responden dengan kategori belum menikah, penghindaran pajak lebih dapat diterima jika tarif pajak tinggi dibandingkan dengan kategori sudah menikah. Hal ini disebabkan karena orang yang sudah menikah lebih terikat pada komunitas sehingga mereka akan menghindari perbuatan yang menimbulkan sanksi sosial seperti penghindaran pajak (Torgler, 2014).

\subsection{Penghindaran pajak lebih dapat diterima ketika pemerintah dianggap korup}

Merujuk pada penelitian yang dilakukan oleh Alasfour, et al. (2016), variabel persepsi korupsi dinilai dengan lima indikator yang pada intinya menyatakan bahwa penghindaran pajak dapat diterima jika uang pajak digunakan untuk hal yang bertentangan dengan moral dan etika atau dikorupsi. Hasil penelitian menunjukkan bahwa rata-rata variabel persepsi korupsi memiliki perbedaan dengan variabel lain terhadap tax morale. Mayoritas rata-rata pernyataan persepsi korupsi lebih tinggi jika dibandingkan dengan rata-rata pernyataan lain, kecuali variabel tarif pajak, persepsi keadilan, dan financial constraint. Artinya selain variabel tarif pajak, persepsi keadilan, dan financial constraint, penghindaran pajak lebih dapat diterima dalam hal uang pajak dikorupsi dibandingkan dengan variabel lain.

Berdasarkan hasil survei dari Transparency International, pada tahun 2020 Indeks Persepsi Korupsi Indonesia turun tiga poin dibandingkan tahun 2019. Penurunan ini adalah yang paling signifikan selama delapan tahun terakhir (Suyatmiko, 2021). Pandemi Covid-19 yang mulai masuk di Indonesia pada tahun 2020, tidak hanya menyebabkan krisis kesehatan tetapi juga krisis ekonomi. Manajemen krisis yang baik dalam penanganan pandemi menjadi suatu hal yang urgensi. Namun, kondisi ini justru dimanfaatkan oleh oknum yang tidak bertanggungjawab untuk memperkaya diri sendiri. Sumber daya fiskal dalam jumlah besar untuk pemulihan kesehatan, ekonomi, dan sosial, justru dimanfaatkan oleh oknum yang tidak bertanggung jawab untuk melakukan korupsi. Menurut Torgler (2003) pemerintah memiliki kekuasaan dalam mengalokasikan sumber daya yang dapat meningkatkan korupsi. Hal tersebut dapat meningkatkan ketidakpercayaan masyarakat terhadap pemerintah. Penghindaran pajak merupakan sinyal dari wajib pajak dalam mengungkapkan ketidaksetujuan mereka terhadap perilaku pemerintah yang korup.

Hal ini sejalan dengan theory of planned behavior, bahwa seseorang melakukan sesuatu karena memiliki keyakinan atas perbuatan tersebut. Menurut Braithwaite, Reinhart, \& Smart (2010), seseorang membenarkan penghindaran pajak karena menganggap pemerintah tidak memanfaatkan uang pajak dengan baik dan hal ini dapat menurunkan voluntary compliance dalam jangka panjang. Sebaliknya, jika wajib pajak percaya kepada pemerintah, maka dapat meningkatkan keinginannya untuk patuh melaksanakan kewajiban perpajakannya (Alm \& Torgler, 2011). Hal ini juga sejalan dengan teori slippery slope bahwa dimensi kepercayaan 
merupakan salah satu faktor yang mempengaruhi kepatuhan pajak. Kepercayaan yang tinggi mengarah pada kepatuhan yang lebih tinggi. Dalam hal kepercayaan menurun akibat perbuatan korup yang dilakukan oleh pejabat pemerintah, maka akan menimbulkan keengganan bagi wajib pajak untuk membayar pajak dan menurunkan tax morale. Hal ini menunjukkan bahwa perilaku korupsi berdampak negatif pada tax morale dan meningkatkan toleransi terhadap penghindaran pajak sebagaimana penelitian yang dilakukan oleh Torgler (2003), Alasfour et al., (2016), dan Williams dan Krasniqi (2017).

\subsection{Penghindaran pajak kurang dapat diterima ketika pemerintah membelanjakan uang pajak secara efektif}

Dalam penelitian ini, variabel efisiensi belanja pemerintah diukur menggunakan tiga indikator dengan pernyataan terkait apakah pemerintah membelanjakan uang pajak dengan bijak dan apakah belanja pemerintah dirasakan manfaatnya oleh masyarakat. Hasil penelitian menunjukkan bahwa rata-rata variabel persepsi efisiensi belanja pemerintah memiliki perbedaan dengan variabel lain terhadap tax morale. Mayoritas rata-rata pernyataan efisiensi belanja pemerintah lebih rendah jika dibandingkan dengan rata-rata pernyataan lain, kecuali variabel referent group dan personal interest. Dengan demikian, dapat disimpulkan bahwa selain untuk variabel referent group dan personal interest, hipotesis kedua diterima.

Sehubungan dengan manajemen krisis yang terjadi di Indonesia, masih terdapat celah inefisiensi dalam pengelolaan sumber daya untuk penanganan pandemi. Contohnya adalah penyaluran dana bantuan sosial (bansos) yang rentan terjadi penyalahgunaan sehingga manfaat yang seharusnya dirasakan oleh pihak yang berhak mendapat bantuan menjadi tidak tepat sasaran. Hal ini disebabkan karena belum adanya sistem yang transparan dan akuntabel baik dari tingkat pusat maupun daerah (Alfedo \& Azmi, 2020). Lemahnya transparansi dan akuntabilitas penggunaan dana publik ini dapat mempengaruhi ketidakpercayaan masyarakat terhadap pemerintah yang pada akhirnya diyakini dapat meningkatkan penghindaran pajak (Pashev, 2005).

Berdasarkan theory of planned behavior, intensi berperilaku dilakukan jika seseorang menganggap perilaku tersebut akan bermanfaat baginya. Tax morale akan lebih tinggi ketika individu merasakan manfaat dalam bentuk barang atau layanan publik sebagai imbalan atas kontribusi pajak yang ia bayarkan (Feld \& Frey, 2007; Alm et al., 1992). Hal ini sejalan dengan penelitian yang dilakukan oleh Biru (2020) dan Alasfour et al. (2016), yang menunjukkan hasil bahwa semakin tinggi persepsi terhadap kualitas atau efisiensi belanja pemerintah, maka akan semakin meningkatkan tax morale dan menurunkan intensi untuk melakukan penghindaran pajak.

\subsection{Penghindaran pajak lebih dapat diterima ketika sistem pajak dianggap tidak adil}

Variabel persepsi keadilan dalam penelitian ini diukur dengan pernyataan apakah penghindaran pajak dapat diterima jika sistem perpajakan di Indonesia tidak adil. Hasil penelitian menunjukkan bahwa rata-rata variabel persepsi keadilan memiliki perbedaan dengan variabel lain terhadap tax morale. Rata-rata pernyataan persepsi keadilan lebih tinggi dibandingkan dengan semua rata-rata pernyataan lain, kecuali variabel persepsi korupsi. Hal ini menunjukkan bahwa penghindaran pajak lebih dapat diterima ketika sistem perpajakan tidak adil dibandingkan dengan pernyataan lain, kecuali ketika pemerintah dianggap melakukan korupsi. Hasil ini sejalan dengan penelitian yang dilakukan oleh Vythelingum et al. (2017) menemukan adanya hubungan positif antara ketidakadilan dengan penghindaran pajak. 
Menurut Feld \& Frey (2002), wajib pajak merespon perlakuan yang diterima dari otoritas pajak ketika memutuskan untuk mematuhi kewajiban perpajakan. Secara keseluruhan, perlakuan yang adil dalam bentuk procedural justice merupakan elemen utama dalam memperoleh kerjasama dan kepercayaan individu (De Cremer \& Tyler, 2007). Hal ini sejalan dengan equity theory yang menyatakan bahwa procedural justice berhubungan dengan tax (non-) compliance dan tax morale (Verboon \& Goslinga, 2009). Wajib pajak akan menjadi kurang (lebih) patuh ketika mereka menjadi korban (penerima manfaat) dari ketidakadilan pajak.

Menurut Hasseldine dan Li (1999), pemerintah memiliki peran penting dalam penghindaran pajak melalui perancangan dan penegakan sistem perpajakan, serta pengumpulan pajak. Oleh karena itu, untuk meningkatkan tingkat kepatuhan pajak, otoritas pajak perlu untuk merancang sistem perpajakan yang memberikan keadilan bagi wajib pajak. Kebijakan di Indonesia terkait peraturan perpajakan untuk kategori UMKM yang memiliki peredaran bruto tertentu sudah diatur dalam PP 46 Tahun 2013 yang kemudian diganti dengan PP 23 Tahun 2018. Dengan adanya kebijakan tersebut diharapkan pelaku UMKM merasa diperlakukan adil karena diberi kesempatan untuk memilih menggunakan tarif pajak umum bagi wajib pajak yang memiliki peredaran bruto tertentu dan sudah mampu melakukan pembukuan. Apabila pelaku UMKM merasa diperlakukan secara adil dan netral maka dapat membangun kepercayaan wajib pajak kepada otoritas pajak dan pada akhirnya dapat meningkatkan tax morale mereka. Kepercayaan merupakan dimensi penting yang mempengaruhi voluntary compliance sebagaimana dimaksud dalam teori slippery slope. Hal ini sejalan dengan penelitian yang dilakukan oleh Hassan, et al. (2021) dan Alasfour et al. (2016) bahwa persepsi keadilan dapat meningkatkan tax morale yang pada akhirnya meningkatkan voluntary compliance wajib pajak dan menurunkan persepsi penghindaran pajak.

\subsection{Penghindaran pajak lebih dapat diterima ketika tarif pajak tinggi}

Variabel tarif pajak dalam penelitian ini diukur dengan pernyataan apakah penghindaran pajak dapat diterima jika tarif pajak tinggi. Hasil penelitian menunjukkan bahwa rata-rata variabel tarif pajak memiliki perbedaan dengan variabel lain terhadap tax morale. Mayoritas ratarata pernyataan tarif pajak lebih tinggi jika dibandingkan dengan rata-rata pernyataan lain, kecuali variabel persepsi keadilan dan persepsi korupsi. Hal ini menunjukkan bahwa penghindaran pajak lebih dapat diterima ketika tarif pajak tinggi dibandingkan dengan variabel lain, kecuali dalam hal sistem perpajakan tidak adil atau uang pajak dikorupsi.

Beberapa penelitian menunjukkan tarif pajak memberikan dampak yang masih diperdebatkan terhadap penghindaran pajak. Menurut Kirchler et al. (2008), menurunkan tarif pajak tidak selalu dapat menurunkan tingkat penghindaran pajak dan meningkatkan tarif pajak tidak serta merta menurunkan kepatuhan pajak (Allingham \& Sandmo, 1972). Tarif pajak untuk pelaku UMKM di Indonesia berdasarkan PP 23 Tahun 2018, sudah tergolong rendah yaitu sebesar $0,5 \%$ dari peredaran bruto. Penurunan tarif dari sebelumnya $1 \%$ menjadi $0,5 \%$ diharapkan dapat memberi rasa keadilan sehingga para pelaku UMKM dapat membayar pajak sesuai kemampuan. Selain itu, pemerintah juga memberikan insentif PPh final ditanggung Pemerintah yang diberikan kepada para pelaku UMKM di masa pandemi yang berlaku hingga akhir tahun 2020 berdasarkan PMK 82/PMK.03/2021 tentang perubahan atas PMK 9/PMK.03/2021. Dengan adanya aturan ini, diharapkan para pelaku UMKM merasa pemerintah hadir membantu mereka dalam memulihkan perekonomian dan dapat meningkatkan kepercayaan terhadap pemerintah dalam menghadapi situasi pandemi.

Menurut Kirchler, et al. (2008), tingkat kepercayaan wajib pajak terhadap pemerintah memiliki peran utama dalam memberikan dampak positif tarif pajak terhadap penghindaran pajak. Jika tingkat kepercayaan rendah dan tarif pajak tinggi, dapat dianggap sebagai suatu 
perlakuan tidak adil terhadap wajib pajak. Namun jika tingkat kepercayaan tinggi dengan tarif pajak yang sama akan diinterpretasikan sebagai kontribusi kepada masyarakat. Hal ini sejalan dengan teori slippery slope yang menyatakan bahwa dimensi kepercayaan dan kekuasaan saling melengkapi. Jika kekuasaan lemah dalam hal ini tarif pajak rendah, maka dimensi kepercayaan menjadi penting. Sebaliknya, jika kekuasaan kuat atau tarif pajak tinggi maka dimensi kepercayaan menjadi tidak relevan. Torgler (2007) berpendapat bahwa dalam situasi dimana orang percaya bahwa sistem pajak tidak adil seperti pengenaan tarif pajak yang tinggi, kecenderungan untuk berperilaku jujur berkurang dan penghindaran pajak dapat dilihat sebagai usaha pertahanan diri.

\subsection{Penghindaran pajak lebih dapat diterima ketika seseorang mengalami kesulitan keuangan}

Dalam penelitian ini, variabel financial constraint diukur dengan pernyataan apakah penghindaran pajak dapat diterima jika tidak mampu membayar pajak. Hasil penelitian menunjukkan bahwa rata-rata variabel financial constraint memiliki perbedaan dengan variabel lain terhadap tax morale. Mayoritas rata-rata pernyataan financial constraint lebih tinggi jika dibandingkan dengan rata-rata pernyataan lain, kecuali variabel tarif pajak, persepsi keadilan, dan persepsi korupsi. Dengan demikian, penghindaran pajak lebih dapat diterima ketika seseorang mengalami kesulitan keuangan dibandingkan dengan variabel lain, kecuali dalam hal tarif pajak tinggi, sistem pajak tidak adil, dan uang pajak dikorupsi.

Terkait financial constraint, hasil yang menunjukkan bahwa wajib pajak yang memiliki kesulitan keuangan rentan untuk melakukan penghindaran pajak konsisten dengan hasil penelitian yang dilakukan oleh Abdul (2001). Seseorang yang memiliki kesulitan keuangan cenderung untuk membuat prioritas keuangan untuk memenuhi kebutuhan hidup dibandingkan untuk membayar pajak. Terlebih di masa pandemi dimana para pelaku usaha mengalami penurunan omzet yang signifikan, bahkan tidak sedikit yang akhirnya menutup usaha mereka karena cashflow yang sulit, membuat mereka harus memprioritaskan keuangan untuk kebutuhan yang mendesak. Hal ini sesuai dengan theory of planned behavior dimana intensi berperilaku dipengaruhi oleh sumber daya yang dimiliki. Jika sumber daya, dalam hal ini kemampuan finansial, yang dimiliki terbatas, maka intensinya untuk memenuhi kewajiban perpajakan akan semakin lemah dan cenderung untuk melakukan penghindaran pajak. Hal ini sejalan dengan penelitian yang dilakukan oleh Wardani (2018) bahwa financial constraint memperkuat pengaruh positif kecenderungan penghindaran pajak terhadap risiko atas pembayaran pajak di masa depan.

\section{SIMPULAN}

Penelitian ini bertujuan untuk mengetahui perbedaan pengaruh variabel persepsi korupsi, efisiensi belanja pemerintah, persepsi keadilan, tarif pajak, dan financial constraint terhadap tax morale. Data dalam penelitian ini diperoleh dengan menyebarkan kuesioner kepada pelaku UMKM di wilayah Jabodetabek secara daring dengan metode convenience sampling. Selama periode penyebaran kuesioner, penulis dapat memperoleh jawaban dari 167 responden.

Berdasarkan hasil uji Z yang dilakukan dapat disimpulkan bahwa penghindaran pajak lebih dapat diterima ketika pemerintah dianggap korup kecuali dalam hal tarif pajak tinggi, sistem pajak tidak adil, dan seseorang mengalami kesulitan keuangan. Sesuai dengan hipotesis awal, hasil pengujian menunjukkan bahwa penghindaran pajak lebih dapat diterima ketika pemerintah dianggap korup dibandingkan dengan pernyataan lain. Namun dalam situasi tarif pajak tinggi, sistem pajak tidak adil, dan kesulitan keuangan yang dialami seseorang, persepsi penghindaran pajak lebih dapat diterima jika dibandingkan dengan uang pajak dikorupsi. 
Berdasarkan hasil uji hipotesis yang kedua, penghindaran pajak kurang dapat diterima ketika pemerintah membelanjakan uang pajak secara efektif kecuali untuk pernyataan terkait personal interest dan referent group. Selain pernyataan terkait personal interest dan referent group, rata-rata variabel efisiensi belanja pemerintah lebih rendah dibandingkan dengan ratarata pernyataan lain. Jadi dapat disimpulkan bahwa penghindaran pajak kurang dapat diterima ketika pemerintah membelanjakan uang pajak secara efektif kecuali ketika orang lain dianggap melakukan penghindaran pajak atau ketika dengan melakukan penghindaran pajak dapat memberi keuntungan bagi orang tersebut.

Selanjutnya, penghindaran pajak lebih dapat diterima ketika sistem pajak dianggap tidak adil, kecuali untuk pernyataan variabel persepsi korupsi. Berdasarkan hasil pengujian hipotesis ketiga dapat disimpulkan bahwa persepsi penghindaran pajak lebih dapat diterima ketika sistem perpajakan tidak adil dibandingkan dengan pernyataan lain selain pernyataan 4 dan 11 (indikator untuk mengukur variabel persepsi korupsi). Dengan demikian, penghindaran pajak lebih dapat diterima ketika sistem perpajakan tidak adil dibandingkan dengan variabel lain, kecuali ketika pemerintah dianggap melakukan korupsi.

Hasil uji hipotesis yang keempat menunjukkan bahwa penghindaran pajak lebih dapat diterima ketika tarif pajak tinggi, kecuali dalam hal sistem perpajakan tidak adil atau uang pajak dikorupsi. Dengan melihat perbandingan rata-rata pernyataan nomor 1 (tarif pajak) dengan pernyataan lain dapat disimpulkan bahwa HO ditolak kecuali untuk pernyataan 3 (persepsi keadilan), 4, 6, dan 11 (persepsi korupsi). Dengan demikian, penghindaran pajak lebih dapat diterima ketika tarif pajak tinggi dibandingkan dengan pernyataan lain, kecuali dalam hal sistem perpajakan tidak adil atau uang pajak dikorupsi.

Terakhir, penghindaran pajak lebih dapat diterima ketika seseorang mengalami kesulitan keuangan, kecuali dalam hal tarif pajak tinggi, sistem pajak tidak adil, dan uang pajak dikorupsi. Untuk hipotesis kelima, hasil pengujian menunjukkan bahwa penghindaran pajak lebih dapat diterima ketika seseorang mengalami kesulitan keuangan dibandingkan dengan pernyataan lain. Namun dalam hal tarif pajak tinggi, sistem pajak tidak adil, dan uang pajak dikorupsi, persepsi penghindaran pajak lebih dapat diterima jika dibandingkan dengan ketika seseorang mengalami kesulitan keuangan.

Selain kesimpulan dari hasil uji hipotesis, dalam penelitian ini juga ditarik kesimpulan dari hasil analisis varians dan perbedaan rata-rata (mean difference) antar variabel. Berdasarkan hasil analisis varians, dapat disimpulkan bahwa tax morale antar kategori usia memiliki perbedaan signifikan. Sementara pada variabel karakteristik lainnya tidak menunjukkan adanya perbedaan signifikan. Untuk kategori usia, kelompok yang memiliki tax morale paling tinggi adalah kelompok usia di bawah 30 tahun. Hal ini mungkin disebabkan kelompok usia tersebut memiliki kemampuan literasi digital untuk mengakses pengetahuan pajak dan memenuhi kewajiban perpajakan yang lebih tinggi dibandingkan kelompok usia lainnya. Kemudian untuk kelompok tax morale tertinggi selanjutnya adalah kelompok usia di atas 49 tahun. Hal ini dapat terjadi karena pada kelompok usia tersebut lebih menghindari perbuatan yang menyebabkan suatu risiko terjadi (risk avoidance) seperti risiko dari melakukan penghindaran pajak.

Untuk kategori status perkawinan terdapat perbedaan signifikan untuk variabel tarif pajak. Untuk responden dengan kategori belum menikah, penghindaran pajak lebih dapat diterima jika tarif pajak tinggi dibandingkan dengan kategori sudah menikah. Hal ini dapat disebabkan karena orang yang sudah menikah lebih terikat pada komunitas sehingga mereka akan menghindari perbuatan yang menimbulkan sanksi sosial seperti penghindaran pajak.

Penelitian ini memiliki keterbatasan sebagaimana penelitian pada umumnya, antara lain tax morale yang diteliti dalam penelitian ini terbatas pada variabel yang ditentukan penulis, 


\section{9 | Bina Ekonomi}

sehingga masih memungkinkan untuk menggunakan variabel lain agar memberikan hasil yang lebih bervariasi. Kemudian instrumen yang digunakan dalam penelitian ini menggunakan kuesioner dengan pernyataan tertutup. Hal ini dapat menimbulkan jawaban bias dan hasil analisis terbatas pada jawaban yang diberikan responden. Selain itu, jumlah responden penelitian hanya mewakili sebagian kecil dari populasi pelaku UMKM di wilayah Jabodetabek mengingat keterbatasan waktu penelitian dan kondisi pandemi Covid-19 yang sedang terjadi.

Berdasarkan hasil pembahasan dan keterbatasan yang terdapat dalam penelitian ini, terdapat beberapa saran bagi DJP sebagai otoritas pajak. Penelitian ini membuktikan bahwa dengan menurunkan tingkat korupsi, meningkatkan efisiensi belanja pemerintah, meningkatkan keadilan, menurunkan tarif pajak, dan mengatasi financial constraint, dapat meningkatkan moral dan kepatuhan pajak. Selain itu, penelitian ini juga dapat menjadi pertimbangan untuk merumuskan panduan dalam menentukan prioritas penyuluhan dan pengawasan berdasarkan kategori usia dalam rangka meningkatkan kepatuhan pajak khususnya bagi pelaku UMKM di wilayah Jabodetabek.

Bagi penelitian selanjutnya disarankan menggunakan indikator lain untuk mengukur tax morale seperti World Value Survey yang telah banyak digunakan dalam penelitian sebelumnya (Alm \& Torgler, 2006; Torgler, 2006; OECD, 2019), sehingga dapat memperkuat hasil pengujian dari variabel yang digunakan dalam penelitian ini terhadap tax morale. Penelitian selanjutnya juga dapat mempertimbangkan untuk menggunakan variabel lain yang mungkin dapat menjelaskan dengan lebih baik pengaruhnya terhadap tax morale khususnya bagi pelaku UMKM dalam mematuhi kewajiban perpajakannya, serta menggunakan mix method dengan melakukan wawancara kepada pelaku UMKM untuk memperoleh hasil analisis yang lebih mendalam. 


\section{DAFTAR PUSTAKA}

\section{Buku Akademik dan Jurnal}

Abdul, M. (2001). Personal income tax non-compliance in Malaysia. PhD Thesis. Victoria University, Melbourne, Australia.

Alm, J., \& Torgler, B. (2006). Culture differences and Tax Morale in the United States and in Europe. Journal of Economic Psychology, 27(2), 224-246.

Alm, J., \& Torgler, B. (2011). Do ethics matter? Tax compliance and morality. Journal of Business Ethics, 101(4), 635-651.

Alasfour, F., Samy, M., \& Bampton, R. (2016). The Determinants of Tax Morale and Tax Compliance: Evidence from Jordan. In Advances in Taxation (Vol. 23, pp. 125-171). https://doi.org/10.1108/S1058-749720160000023005

Alfedo, J. M., \& Azmi, R. H. N. (2020). Sistem Informasi Pencegahan Korupsi Bantuan Sosial Si Pansos) di Indonesia: Rumusan Konsep dan Pengaturan. INTEGRITAS: Jurnal Antikorupsi, 6(2), 283-296. https://doi.org/10.32697/integritas.v6i2.668

Allingham, M. G., \& Sandmo, A. (1972). Income tax evasion: a theoretical analysis. Journal of Public Economics, 1(3-4), 323-338. https://doi.org/10.1016/0047-2727(72)90010-2

Alm, J., McClelland, G. H., \& Schulze, W. D. (1992). Why do people pay taxes? Journal of Public Economics, 48(1), 21-38. https://doi.org/10.1016/0047-2727(92)90040-M

Andreoni, J., Feinstein, J., \& Erard, B. (1998). Tax Compliance. In Tax Compliance (Issue Jun, pp. 818-860). Gabler. https://doi.org/10.1007/978-3-8349-8282-7_12

Biru, A. M. (2020). Factors That Affect Tax Compliance Behavior of Small and Medium Enterprises: Evidence from Nekemte City. European Journal of Business and Management, 12(19), 29-41. https://doi.org/10.7176/ejbm/12-19-04

Bitzenis, A., \& Vlachos, V. (2018). Tax morale in times of economic depression: The case of greece. Advances in Taxation, 25(November), 173-199. https://doi.org/10.1108/S1058749720180000025008

Braithwaite, V., Reinhart, M., \& Smart, M. (2010). Tax non-compliance among the under-30s: Knowledge, obligation or scepticism? [www]. Retrieved from http://vab.anu.edu.au/present/agetax.pdf.

Çevik, S. (2016). Tax morale and tax compliance in socio-political context. Political Economy of Taxation, Istanbul: IJOPEC, 37-57.

Clotfelter, C.T. 1983, Tax Evasion and Tax Rates: An Analysis of Individual Returns, Review of Economics and Statistics, vol. 65, pp. 363-373.

De Cremer, D., \& Tyler, T. (2007). The effects of trust in authority and procedural fairness on cooperation. Journal of Applied Psychology, 92(3), 639-649.

Erard, B., \& Feinstein, J. S. (1994). The Role of Moral Sentiments and Audit Perceptions in Tax 
151 | Bina Ekonomi

Compliance. The Role of Moral Sentiments and Audit Perceptions in Tax Compliance, 49(August), 70-89.

Feld, L. P., \& Frey, B. S. (2007). Tax Compliance as the Result of a Psychological Tax Contract: The Role of Incentives and Responsive Regulation. Law \& Policy, 29(1), 102-120. https://doi.org/10.1111/j.1467-9930.2007.00248.x

FREY, B. \& FELD, L. 2002. Deterrence and Morale in Taxation: An Empirical Analysis. CESifo Working Paper Series No 760. August 2002 ed. SSRN Website

Frey, B. S., \& Torgler, B. (2007). Tax morale and conditional cooperation. Journal of Comparative Economics, 35(1), 136-159. https://doi.org/10.1016/j.jce.2006.10.006

GRAETZ, M. J. \& WILDE, L. L. 1985. The Economics of Tax Compliance: Fact and Fantasy. National Tax Journal, 38(3), 355 - 363.

Hassan, I., Naeem, A., \& Gulzar, S. (2021). Voluntary tax compliance behavior of individual taxpayers in Pakistan. Financial Innovation, 7(1). https://doi.org/10.1186/s40854-02100234-4.

Hasseldine, J., \& Li, Z. (1999). More tax evasion research required in new millennium. Crime, Law and Social Change, 31(1), 91-104.

Horodnic, I. A. (2018). Tax morale and institutional theory: a systematic review. International Journal of Sociology and Social Policy, 38(9/10), 868-886. https://doi.org/10.1108/IJSSP03-2018-0039.

Jahnke, B., Weisser, R.A., How does petty corruption affect tax morale in Sub-Saharan Africa?, European Journal of Political Economy (2018), https://doi.org/10.1016/j.ejpoleco.2018.09.003 Jahnke, B., Weisser, R.A., How does petty corruption affect tax morale in Sub-Saharan Africa?, European Journal of Political Economy (2018), https://doi.org/10.1016/j.ejpoleco.2018.09.003 Jahnke, B., Weisser, R.A., How does petty corruption affect tax morale in Sub-Saharan Africa?, European Journal of Political Economy (2018), https://doi.org/10.1016/j.ejpoleco.2018.09.003 Jahnke, B., Weisser, R.A., How does petty corruption affect tax morale in Sub-Saharan Africa?, European Journal of Political Economy (2018), https://doi.org/10.1016/j.ejpoleco.2018.09.003 Jahnke, B., Weisser, R.A., How does petty corruption affect tax morale in Sub-Saharan Africa?, European Journal of Political Economy (2018), https://doi.org/10.1016/j.ejpoleco.2018.09.003 Jahnke, B., Weisser, R.A., How does petty corruption affect tax morale in Sub-Saharan Africa?, European Journal of Political Economy (2018), https://doi.org/10.1016/j.ejpoleco.2018.09.003 Jahnke, B., Weisser, R.A., How does petty corruption affect tax morale in Sub-Saharan Africa?, European Journal of Political Economy (2018), https://doi.org/10.1016/j.ejpoleco.2018.09.003 Jahnke, B., Weisser, R.A., How does petty corruption affect tax morale in Sub-Saharan Africa?, European Journal of Political Economy (2018), https://doi.org/10.1016/j.ejpoleco.2018.09.003 Jahnke, B., Weisser, R.A., How does petty corruption affect tax morale in Sub-Saharan Africa?, European Journal of Political Economy (2018), https://doi.org/10.1016/j.ejpoleco.2018.09.003 Jahnke, B., Weisser, R.A., How does petty corruption affect tax morale in Sub-Saharan Africa?, European Journal of Political Economy (2018), https://doi.org/10.1016/j.ejpoleco.2018.09.003 Jahnke, B., Weisser, R.A., How does petty corruption affect tax morale in Sub-Saharan Africa?, European Journal of Political Economy (2018), https://doi.org/10.1016/j.ejpoleco.2018.09.003 
Kirchler, E. (2007). The economic psychology of tax behaviour. Cambridge University Press.

Kirchler, E., Hoelzl, E., \& Wahl, I. (2008). Enforced versus voluntary tax compliance: The "slippery slope" framework. Journal of Economic Psychology, 29(2), 210-225. https://doi.org/10.1016/j.joep.2007.05.004.

OECD. (2019). What is Driving Tax Morale? https://www.oecd.org/tax/tax-global/publicconsultation-document-what-is-driving-tax-morale.pdf

Ortega, D., Ronconi, L., \& Sanguinetti, P. (2012). Reciprocity and Willingness to Pay Taxes: Evidence from a Survey Experiment in Latin America. Economia, 16(2), 55-87. https://doi.org/10.13140/RG.2.1.3060.5283

Pashev, K. (2005). Tax compliance of small business in transition economies: Lessons from Bulgaria [www]. Retrieved from: icepp.gsu.edu/sites/default/files/documents/icepp/wp/ ispwp0510.pdf.

Sari, N. P. R., \& Maradona, A. F. (2020). Kenapa Wajib Pajak UMKM Enggan Membayar Pajak $\begin{array}{llll}\text { Penghasilan? } & \text { E-Jurnal } & \text { 30(6), } & \end{array}$ https://doi.org/10.24843/EJA.2020.v30.i06.p17

Suyatmiko, W. H. (2021). Memaknai Turunnya Skor Indeks Persepsi Korupsi Indonesia Tahun 2020. Integritas, 7(1), 161-178. https://doi.org/10.32697/integritas.v7i1.717

Torgler, B. (2003). Tax morale, rule governed behaviour and trust. Constitutional Political Economy, 14(2), 119-140.

Torgler, B. (2005). Tax morale and direct democracy. European Journal of Political Economy, 21(2), 525-531. https://doi.org/10.1016/j.ejpoleco.2004.08.002.

Torgler, B. (2006). The importance of faith: Tax morale and religiosity. Journal of Economic Behavior and Organization, 61(1), 81-109.

Torgler, B. (2007). Tax Compliance and Tax Morale. In Tax Compliance and Tax Morale: A Theoretical and Empirical Analysis. Edward Elgar Publishing Limited. https://doi.org/10.4337/9781847207203.

Torgler, B. (2012). Tax morale, Eastern Europe and European enlargement. Communist and PostCommunist Studies, 45(1), 11-25.

Torgler, B. (2014). Cross Culture Comparision of Tax Morale and Tax Compliance. January 2004. https://doi.org/10.2307/41954393.

Torgler, B., \& Schaltegger, C. a. (2005). Tax morale and fiscal policy (Unpublished Working Paper No. 1748). Center for Research in Economics, Management and the Arts. 1-34.

Torgler, B., \& Valev, N. T. (2010). Gender and Public Attitudes Toward Corruption and Tax Evasion. Contemporary Economic Policy, 28(4), 554-568. https://doi.org/10.1111/j.14657287.2009.00188.x 
153 | Bina Ekonomi

Torgler, B., Schneider, F., \& Schaltegger, C. (2010). Local autonomy, tax morale, and the shadow economy. Public Choice, 144, 293-321.

Verboon, P., \& Goslinga, S. (2009). The role of fairness in tax compliance. Netherlands Journal of Psychology, 65(4), 136-145. https://doi.org/10.1007/BF03080136

Vythelingum, P., Soondram, H., \& Jugurnath, B. (2017). An assessment of tax morale among Mauritian taxpayers. Journal of Accounting and Taxation, 9(1), 1-10. https://doi.org/10.5897/JAT2016.0224

Wardani, D. K., (2018). Pengaruh Kecenderungan Penghindaran Pajak Terhadap Risiko Dengan Corporate Governance \& Financial Constraint Sebagai Pemoderasi. Repository UGM. [Doctoral Dissertation, Gajah Mada University].

Williams, C. C., \& Krasniqi, B. (2017). Evaluating the individual- and country-level variations in tax morale. Journal of Economic Studies, 44(5), 816-832. https://doi.org/10.1108/JES-09-20160182

\section{Peraturan dan Dokumen Publik Lainnya}

Republik Indonesia. (2008). Undang-Undang Nomor 20 Tahun 2008 tentang Usaha Mikro Kecil Menengah.

Republik Indonesia. (2013). Peraturan Pemerintah Nomor 46 Tahun 2013 tentang Pajak Penghasilan atas Penghasilan dari Usaha yang Diterima atau Diperoleh Wajib Pajak yang Memiliki Peredaran Bruto Tertentu.

Republik Indonesia. (2018). Peraturan Pemerintah Nomor 23 Tahun 2018 tentang Pajak Penghasilan atas Penghasilan dari Usaha yang Diterima atau Diperoleh Wajib Pajak yang Memiliki Peredaran Bruto Tertentu.

Republik Indonesia. (2021). Peraturan Pemerintah Nomor 7 Tahun 2021 tentang Kemudahan, Pelindungan, dan Pemberdayaan Koperasi dan Usaha Mikro, Kecil, dan Menengah.

Republik Indonesia (2021). Peraturan Menteri Keuangan Nomor 82/PMK.03/2021 tentang Perubahan atas Peraturan Menteri Keuangan Nomor 9/PMK.03/2021 tentang Insentif Pajak untuk Wajib Pajak Terdampak Pandemi Corona Virus Disease 2019. 
Lampiran 1 Tabel Statistik Deskriptif

\begin{tabular}{|c|c|c|c|c|c|c|c|}
\hline & FREKUENSI & TM & COR & GOV & FAIR & TR & FC \\
\hline \multicolumn{8}{|l|}{ Jenis Kelamin } \\
\hline Pria & 52 & $4.24(1.34)$ & 4.97 & 2.98 & 5.60 & 5.13 & 5.00 \\
\hline Wanita & 115 & $4.15(0.95)$ & 4.71 & 3.46 & 5.49 & 5.30 & 4.79 \\
\hline \multicolumn{8}{|l|}{ Usia } \\
\hline$<30$ tahun & 41 & $3.82(1.39)$ & 4.46 & 3.04 & 5.10 & 4.66 & 4.27 \\
\hline 30-39 tahun & 50 & $4.55(1.00)$ & 5.03 & 3.89 & 5.20 & 5.42 & 5.30 \\
\hline 40-49 tahun & 47 & $4.19(0.76)$ & 4.88 & 3.04 & 6.19 & 5.36 & 5.11 \\
\hline$>49$ tahun & 29 & $4.03(1.01)$ & 4.70 & 3.11 & 5.59 & 5.62 & 4.52 \\
\hline \multicolumn{8}{|l|}{ Status Perkawinan } \\
\hline Menikah & 18 & 4.05 (1.59) & 4.56 & 3.43 & 5.00 & 3.94 & 4.72 \\
\hline Belum menikah & 141 & $4.20(1.30)$ & 4.85 & 3.31 & 5.59 & 5.40 & 4.81 \\
\hline Cerai hidup & 4 & $4.10(0.67)$ & 4.25 & 2.50 & 5.25 & 6.50 & 6.25 \\
\hline Cerai mati & 4 & $4.16(0.55)$ & 4.40 & 3.42 & 5.75 & 4.75 & 5.75 \\
\hline \multicolumn{8}{|l|}{ Tingkat Pendidikan } \\
\hline $\begin{array}{l}\text { SD/SMP/SMA } \\
\text { sederajat }\end{array}$ & 50 & $4.11(0.77)$ & 4.72 & 3.29 & 5.74 & 5.20 & 4.36 \\
\hline DI/DII/DIII & 32 & $3.93(1.41)$ & 4.38 & 3.12 & 5.22 & 4.97 & 5.03 \\
\hline S1/DIV & 75 & $4.25(1.10)$ & 4.95 & 3.28 & 5.47 & 5.33 & 5.03 \\
\hline $\begin{array}{l}\text { Pascasarjana } \\
\text { (Profesi, S2,S3) }\end{array}$ & 10 & $4.79(0.94)$ & 5.30 & 4.17 & 5.80 & 5.80 & 5.50 \\
\hline \multicolumn{8}{|l|}{ Jenis Usaha } \\
\hline Agrikultur & 2 & $4.68(0.37)$ & 6.50 & 2.67 & 6.50 & 6.00 & 7.00 \\
\hline Industri/manufaktur & 12 & $4.24(1.25)$ & 4.98 & 2.94 & 5.50 & 5.25 & 5.33 \\
\hline Informasi & 2 & $3.47(1.66)$ & 4.30 & 2.00 & 4.00 & 4.00 & 6.00 \\
\hline Jasa & 18 & $4.28(1.00)$ & 5.26 & 2.83 & 5.72 & 5.50 & 5.11 \\
\hline Kesehatan & 2 & $4.44(1.04)$ & 4.30 & 3.33 & 4.00 & 6.50 & 6.50 \\
\hline Pendidikan & 7 & $4.05(0.97)$ & 4.86 & 2.62 & 6.57 & 6.29 & 4.00 \\
\hline $\begin{array}{l}\text { Penyediaan } \\
\text { akomodasi, makan } \\
\text { dan minum }\end{array}$ & 58 & $4.22(1.11)$ & 4.64 & 3.55 & 5.69 & 5.31 & 5.02 \\
\hline $\begin{array}{l}\text { Perdagangan besar } \\
\text { dan eceran }\end{array}$ & 66 & $4.12(1.10)$ & 4.74 & 3.42 & 5.27 & 5.00 & 4.50 \\
\hline \multicolumn{8}{|l|}{ Omzet per tahun } \\
\hline $0-300.000 .000$ & 119 & $4.20(1.20)$ & 4.76 & 3.29 & 5.61 & 5.24 & 4.92 \\
\hline $\begin{array}{l}300.000 .001- \\
2.500 .000 .000\end{array}$ & 24 & $3.87(0.69)$ & 4.57 & 3.07 & 4.71 & 5.04 & 4.21 \\
\hline $\begin{array}{l}2.500 .000 .001- \\
4.800 .000 .000\end{array}$ & 15 & $4.61(0.62)$ & 5.41 & 4.18 & 5.40 & 5.47 & 5.33 \\
\hline $\begin{array}{l}4.800 .000 .001- \\
50.000 .000 .000\end{array}$ & 9 & $4.05(0.61)$ & 4.80 & 2.67 & 6.67 & 5.56 & 4.89 \\
\hline $\begin{array}{l}\text { Rata-rata } \\
\text { keseluruhan }\end{array}$ & & 4.18 & 4.82 & 3.18 & 5.48 & 5.33 & 5.12 \\
\hline
\end{tabular}

